\title{
Legitimising the Juba Peace Agreement on Accountability and Reconciliation The International Criminal Court as a Third-party Actor?
}

\section{Gissel, Line Engbo}

Published in:

Journal of Eastern African Studies

DOI:

10.1080/17531055.2017.1303249

Publication date:

2017

Document Version

Peer reviewed version

Citation for published version (APA):

Gissel, L. E. (2017). Legitimising the Juba Peace Agreement on Accountability and Reconciliation: The International Criminal Court as a Third-party Actor? Journal of Eastern African Studies, 11(2), 367-387. https://doi.org/10.1080/17531055.2017.1303249

\section{General rights}

Copyright and moral rights for the publications made accessible in the public portal are retained by the authors and/or other copyright owners and it is a condition of accessing publications that users recognise and abide by the legal requirements associated with these rights.

- Users may download and print one copy of any publication from the public portal for the purpose of private study or research.

- You may not further distribute the material or use it for any profit-making activity or commercial gain.

- You may freely distribute the URL identifying the publication in the public portal.

\section{Take down policy}

If you believe that this document breaches copyright please contact rucforsk@kb.dk providing details, and we will remove access to the work immediately and investigate your claim. 


\title{
Legitimising the Juba Peace Agreement on Accountability and Reconciliation: the International Criminal Court as a third-party actor?
}

\author{
Line Engbo Gissel*
}

Department of Social Sciences and Business, Roskilde University, Roskilde, Denmark

(Received 11 May 2016; accepted 21 December 2016)

\begin{abstract}
This article analyses the Juba peace negotiations on accountability and reconciliation. It advances a new interpretation of the Agreement on Accountability and Reconciliation, focusing on five justice features: National proceedings, restorative accountability, alternative sentencing, individual responsibility and forward-looking victimhood. The article argues that the nature of the agreed justice policy derives from negotiators and mediators' pursuit of international legitimation by the ICC and its compliance constituency. This argument has implications for our understanding of the role of the ICC in internationally judicialised peace processes: The need for peace agreement legitimation combined with the legitimacy requirements in such peace processes structurally constitutes the ICC as metaphorically present in the negotiation room and thus akin to a third-party actor.
\end{abstract}

Keywords: peace negotiations; legitimacy; justice; Lord's Resistance Army; International Criminal Court; Uganda

The failed Juba Peace Talks between the Ugandan government and the Lord's Resistance Army/Movement (LRA/M) took place in the context of involvement by the International Criminal Court (ICC) and sparked the first crisis of legitimacy for the world court. Criticized and disowned by Uganda's civil society and conflict-affected populations, ${ }^{1}$ ICC involvement became controversial and contentious. ${ }^{2}$ At the heart of the crisis was the accountability and reconciliation policy negotiated in Juba: understood by international justice proponents as a challenge to the ICC's legitimacy, the policy raised fears that it would damage the credibility of the Court and expose the latter to 'blackmail' by rebels. ${ }^{3}$ The ICC's Ugandan intervention was accordingly understood as

*Email: lgissel@ruc.dk 
pitting local against international justice. This interpretation, however, misunderstands the nature of the agreement and its quest for international legitimation.

This article advances a new interpretation of the Agreement on Accountability and Reconciliation and its Annexure and uses this understanding to discuss the role of the ICC in internationally judicialised peace processes. The article argues that negotiators and mediators pursued legitimation of the Agreement on Accountability and Reconciliation and its Annexure by the ICC and its compliance constituency. This pursuit structured the agreement in fundamental ways by subjecting its substance and form to the perceived need for international recognition. The result was a complicated and ambiguous agreement, which failed to persuade the LRA/M leadership.

This analysis poses a challenge to the understanding of peace processes that occur in the context of international judicial interventions: It suggests that although the ICC is not formally a party to peace negotiations, it is constituted as a source of legitimacy, akin to third-party actor. Structurally, therefore, the ICC is in the negotiation room.

The article proceeds as follows. It first discusses the need for peace agreement legitimacy, including the legitimation of internationally judicialised peace processes. Then, after a brief background to the Juba negotiations on accountability and reconciliation, it provides a new interpretation of the justice policy. The third part of the article analyses the negotiations and their outputs in terms of the conflict parties' pursuit of legitimation. This part argues that mediators and negotiators' pursuit of legitimation of the peace agreement by the ICC and its supporters structured the agreement in fundamental ways by subjecting its substance and form to the need for international legitimation. Peacemakers therefore formulated a justice policy that in their eyes was compatible with the Rome Statute. These findings give rise to a discussion, in the conclusion, of the role of the ICC in internationally judicialised peace processes. 


\section{Legitimacy in peace negotiations}

Legitimacy characterises the intersubjective acceptance of authority: when actors perceive an institution to be legitimate, they voluntarily accept to obey its rules. ${ }^{4}$ Linked to impact, legitimacy is thought to explain compliance, that is, adherence to institution rules, policies and decisions. ${ }^{5}$ If actors in a conflict network accept the political authority of a negotiated agreement, therefore, they support its implementation; if they view the agreement as illegitimate, they may seek to undermine or violate it. To understand why peacemakers need to actively build the authority of a peace agreement, it is useful to examine the nature of peace processes and their outcomes.

Peace processes are pockets of delegated authority that aim to settle a conflict by means of a politically negotiated solution. Peace processes that seek to end internal and asymmetric conflict constitute departures from normal politics: they rely on a sovereign government bypassing its constitutional law-making processes to sign a document with an unlawful party such as an insurgent army. ${ }^{6}$ While conflict parties delegate power and authority to their respective negotiation teams to enable the negotiation, the initial legitimacy of such peace processes derives from their promise to end violence. As a Colombian peace advocate states, the Havana-based 'negotiations [between Colombia and the insurgent Revolutionary Armed Forces of Colombia] are legitimate because they are seeking to end a 50-year war'. ${ }^{7}$ Where negotiations are controversial, governments may seek popular support for them through elections or referendums. ${ }^{8}$ Whether consent is provided explicitly or implicitly, popular legitimacy empowers the peace negotiators. This procedural legitimacy, however, does not automatically extend to the negotiation outputs: to prevail over supporters of the continuation of conflict, negotiated agreements have to be legitimised. ${ }^{9}$

The legitimation of peace agreements derives from their politically contestable and legally uncertain status. Peace agreements are contestable because they sit within an immediate context of exclusive and exceptional negotiations and a wider context of conflict. The exclusive and 
exceptional context relates to the appointed and unaccountable status of negotiators and the fact that illegitimate actors are included solely by virtue of their capacity to inflict violence. Participants to a peace process are rarely representative of the population; moreover, they are vested with power to negotiate an outcome that may not take the latter's broader interests into account. Peace processes are thus 'inherently un-democratic'. ${ }^{10}$

Peace agreements have uncertain legal status because they sit awkwardly within conventional categories of municipal and international law; this has a bearing upon the degree to which they are considered binding. ${ }^{11}$ Their 'legal-looking structure', public availability, written and signed form and international endorsement suggest that 'the parties mutually view [peace agreements] as legal documents'. ${ }^{12}$ At the same time, they know that their violation of an agreement incur at most political costs. The perceived legality of peace agreements thus does not automatically confer legitimacy. Even if considered a legal agreement between two parties, it is not clear to which politico-legal authority the agreement refers. ${ }^{13}$ The lack of clarity pertaining to their legal status adds to their need for political recognition.

Legitimation is the process by which the exercise of authoritative power is made to be - and maintained as being - acceptable to those subject to it. ${ }^{14}$ De-legitimation, in contrast, denotes a process of contestation that erodes existing or claimed legitimacy. ${ }^{15}$ As authority is not inherent in any institution, it needs to be continuously built, justified and negotiated ${ }^{16}$; this creates an impetus for the institution to acquire, construct and defend its legitimacy, thus engaging in legitimacypursuing behaviour. Goddard argues that conflict resolution in polarised networks rely on 'brokers' to legitimise peace agreements because they can 'frame settlements in ways that resonate across multiple coalitions. ${ }^{, 17}$ However, practices of legitimation are also directed at different constituencies within the conflict parties. ${ }^{18}$ 
Scholarship on legitimation often centres on the idea of 'audience'. ${ }^{19}$ Audiences are constituencies that confer legitimacy on an authority; when these have different values and perspectives, the institution has an 'audience problem'. ${ }^{20}$ In a conflict network, actors dispute norms and rules and attach different meanings to events and symbols; negotiation outcomes therefore need to be portrayed as legitimate to multiple audiences. ${ }^{21}$ This is a difficult task, as 'different coalitions hold distinct, even mutually exclusive understandings of what constitutes a legitimate settlement' ${ }^{22}$ As legitimacy contributes to compliance, the audience problem presents an obstacle to the successful settlement of conflict.

\section{Peace agreement legitimation in conditions of international judicial involvement}

Since the establishment of the International Criminal Tribunal for the Former Yugoslavia in 1993, some peace processes have taken place in the context of international judicial intervention. ${ }^{23}$ Earlier interventions took place in a post-conflict situation, such as the Nuremberg and Tokyo processes following the end of World War II. Due to the nature of crimes under the jurisdiction of the ICC genocide, crimes against humanity, and war crimes - the Court tends to become involved in divided countries at war or in transition, where political negotiations seek to establish political order. This development poses a particular challenge to the legitimation of peace agreements.

The international judicialisation of peace processes delegates politico-legal authority to the international level, ${ }^{24}$ thereby creating a need for their international legitimation. As shown further below, this applies also to their negotiation outputs: Negotiators and mediators in the Juba Peace Talks deliberately crafted an internationally legitimisable agreement and actively - but unsuccessfully - claimed its legitimation by the ICC and its compliance constituency. However, if legitimacy is an intersubjective evaluation by those subject to an institution's authority, how can the ICC legitimise or delegitimise a peace agreement? Clearly, the ICC is not compelled to obey the 
terms of any peace accord. To answer this question, we need to shift the focus to the level of global governance.

Bernstein argues that legitimacy in particular global governance regimes results from the interaction of the affected or regulated community of actors with the international social structure which defines what appropriate authority is and prescribes and proscribes the boundaries of governance activities. ${ }^{25}$ These interactions between community and structure 'create different legitimacy requirements across different issue areas and forms of governance'. ${ }^{26}$ The Rome Statute and the ICC's 'law-in-action' ${ }^{27}$ structures the context within which internationally judicialised peace processes take place by detailing both the appropriate and compulsory responses to the stages in the ICC's criminal process: preliminary examination, investigation, indictment and trial. Once a process has reached the indictment stage, state parties are required to cooperate with the ICC and arrest the indictees; at the same time, the prosecution cannot easily be deferred or withdrawn. Interacting with this hard and soft law structure, the community of actors in the field of international justice work to 'end impunity': eradicate amnesty provisions pertaining to serious human rights violations and hold perpetrators of the latter to account in a formal criminal process. This community includes the ICC's 'compliance constituency', groups of actors who seek to align policy with international law. ${ }^{28}$ The resulting legitimacy requirements for internationally judicialised peace processes concern the appropriate justice response to the atrocities of conflict. While the next part of the article analyses the Juba Talks' negotiated justice policy, the last part explains its ambitious, ambiguous and complicated nature as result of negotiators and mediators' pursuit of international legitimacy.

\section{The Juba negotiations on accountability and reconciliation}

Although much has been written about ICC involvement in Uganda, ${ }^{29}$ the focus on legitimacy enables a new interpretation of the negotiations on accountability and reconciliation. This 
interpretation explains the complicated and ambiguous nature of the Agreement on Accountability and Reconciliation and a subsequent Annexure, both of which have puzzled scholars since their public release. ${ }^{30}$ The interpretation is based on the analysis of interviews, peace agreements, newspaper reports and official third-party documents. Interview data stems from 19 in-depth interviews with persons related to the peace process, particularly negotiators and mediators, between May 2010 and February 2013.

The Juba Peace Talks between the Ugandan government and the LRA/M took place between July 2006 and December 2008 and sought to end their two-decades-long conflict. The conflict originated in the brutality of and discrimination by president Museveni's National Resistance Army after it took Uganda in a coup d'etat in $1986 .{ }^{31}$ The LRA/M perceived itself to be fighting Museveni's government in order to improve the conditions of life in Uganda's northern Acholi region. ${ }^{32}$ Over the years, the LRA/M and the government had talked peace several times, but these interactions were marked by deep-seated distrust and unequal power dynamics. ${ }^{33}$

In late 2005, the regional semi-autonomous government of Southern Sudan initiated the Juba Talks, approaching first the rebels, who had already reached out to Catholic peace NGOs. ${ }^{34}$ As a result, in May 2006, LRA/M leader Joseph Kony recorded a statement expressing a desire 'to talk to Museveni'. ${ }^{35}$ The Ugandan president agreed to a government-LRA/M peace process mediated by Southern Sudan and offered the rebel leadership a security guarantee. According to the Museveni, 'much as Kony and four of his cohorts had been indicted by the International Criminal Court, if he got serious about a peaceful settlement, the Government of Uganda would guarantee him safety'. ${ }^{36}$ He repeated this plan to senior US officials more than a year later, in September $2007 .{ }^{37}$

However, security was not for Museveni to give. Having referred the northern conflict to the ICC in December $2003,{ }^{38}$ Uganda had delegated the LRA/M problem to the 
international level and could not formally regain authority over the issue. The prosecutor initiated an investigation in mid-2004 and in July 2005 the Pre-Trial Chamber authorised the indictment of Kony and four other LRA/M commanders. Commencing in July 2006 in the town of Juba, Southern Sudan, the negotiations thus took place within a context of international judicial involvement.

The Juba Peace Talks were structured according to six agenda items: cessation of hostilities; comprehensive solutions to the conflict; accountability and reconciliation; permanent cease fire; disarmament, demobilisation and reintegration; and implementation and monitoring mechanisms. They ended when the government, supported by the US, bombed the LRA/M camps in December 2008, following the failure by Kony to sign the Final Peace Agreement on two occasions.

\section{The negotiations}

Given the ICC arrest warrants, the negotiations on accountability and reconciliation were 'the most sensitive and most negotiated' part of the peace process. ${ }^{39}$ Issues of accountability, being inextricably linked to the personal fates of key persons, were likely to determine the parties' commitment to the political settlement. The LRA/M leader and his deputy, Kony and Vincent Otti, had repeatedly called for the withdrawal of the arrest warrants; at the opening of the Talks, the LRA/M delegation warned that the 'war [could] only become more intensive' if the ICC arrested the five indictees. ${ }^{40}$

In the context of an insurgency that could not be militarily defeated, negotiators and mediators were faced with the challenge that the LRA/M leaders could neither be prosecuted nor amnestied. They were internationally indicted, could not be apprehended, and were unwilling to submit to a prosecution. Although Ugandan law permitted amnesty for rebels, a solution that amnestied the ICC indictees was perceived as illegal under international law as well as politically unacceptable to the international community. 
The negotiations on accountability and reconciliation began in May 2007. The Cessation of Hostilities Agreement, signed in August 2006, had been violated by both parties, but the LRA had left Ugandan territory and moved towards the agreed assembly areas in Southern Sudan. ${ }^{41}$ Reduced hostilities spurred a short-lived international optimism about the talks, reflected in international funding and the December 2006 appointment of former Mozambican president, Joachim Chissano, as the UN Secretary General's Special Representative for LRA-Affected Areas.

The conflict parties' initial positions on accountability and reconciliation were not too dissimilar; in principle, they agreed on an alternative concept of justice but had to clarify what this meant. The government proposed ways to reintegrate LRA perpetrators, particularly through Uganda's amnesty policy and the Acholi cleansing ritual of mato oput. ${ }^{42}$ This position diverged from the government's strategy of judicialising the conflict and represented the continuation of its earlier, pragmatic approach of settling insurgencies politically. ${ }^{43}$

Prior to the talks, the LRA/M leadership had briefed its delegation on justice issues, particularly on the imperative of accountability for crimes committed by both conflict parties. ${ }^{44}$ The first LRA/M position paper emphasized 'the need for various actors (not least the government) to accept responsibility for causing the conflict, expressed through mechanisms such as traditional justice, a truth and reconciliation commission, and compensation. ${ }^{45}$ A subsequent paper criticized the government for omitting accountability for the army's conduct during the conflict. ${ }^{46}$

In order to work with the issue, negotiators, mediators, and civil society observers took part in a workshop about accountability in the traditional, national legal and Rome Statute systems. ${ }^{47}$ As a result, the conflict parties agreed on a set of principles to guide the further negotiations, including that 'a national legal and institutional framework provides a sufficient basis for ensuring accountability and reconciliation in Uganda with respect to crimes and violations 
committed during the conflict.' ${ }^{48}$ A month later they signed the Agreement on Accountability and Reconciliation.

\section{The proposed solution}

Formalised in the Agreement on Accountability and Reconciliation (signed 29 June 2007) and an Annexure to the Agreement (signed 19 February 2008), the proposed solution was an elaborately defined alternative justice process that would 'resolve the conflict while promoting reconciliation' ${ }^{49}$ The justice policy had five features: National proceedings, a restorative notion of accountability, an alternative penalty and sentencing regime, a focus on individual responsibility, and a forward-looking victim approach. ${ }^{50}$ In order to understand the subsequent legitimation claims, it is necessary to explain the policy's features.

\section{National proceedings}

The justice policy centred on national proceedings: Nobody was going to The Hague. In the Agreement, the parties committed to 'national legal arrangements, consisting of formal and nonformal institutions and measures for ensuring justice and reconciliation with respect to the conflict. ${ }^{51}$ To enable national proceedings, given the ICC indictments, the government agreed to ' $[\mathrm{u}]$ ndertake any necessary representation or legal proceedings nationally or internationally, to implement the principles of this Agreement' and '[a]ddress conscientiously the question of the ICC arrest warrants relating to the leaders of the LRA/M' ${ }^{52}$ These provisions committed the government to lobby key countries to effect a UN Security Council request to defer the ICC process as per Article 16 of the Rome Statute. ${ }^{53}$ The task was explicitly detailed in the Agreement on Implementation and Monitoring, signed 29 Feb 2008. ${ }^{54}$ The Security Council deferral was to be combined with an admissibility challenge to return jurisdiction over the case to the Ugandan justice system. 


\section{Restorative accountability}

The justice policy entailed an alternative accountability process that differed from ordinary criminal accountability: Conventional criminal procedures and imprisonment were not imperative. The alternative nature of the process was implied in the Agreement and detailed in the Annexure. The former entailed the principles that traditional justice mechanisms 'shall be promoted, with necessary modifications, as a central part of the framework for accountability and reconciliation' and that 'any meaningful accountability proceedings should ... promote reconciliation and encourage individuals to take personal responsibility for their conduct. ${ }^{55}$

Accountability was described as a pluralistic notion: While the Agreement stated that alleged perpetrators of serious crimes or human rights violations should be subjected to 'formal criminal and civil justice measures' and state actors should submit to existing criminal justice processes, it also mentioned '[p]rosecutions and other formal accountability proceedings', a 'choice of forum', and an 'adapted legal framework in Uganda'. ${ }^{56}$ The civil justice measures meant 'proceedings seeking compensation to the victim rather than just punishment to the offender'. ${ }^{57}$ The overarching justice framework was to provide for the 'adoption and recognition of complementary alternative justice mechanisms', while, importantly, '[a]lternative justice mechanisms shall promote reconciliation and shall include traditional justice processes, alternative sentences, reparations, and any other formal institutions or mechanisms'. ${ }^{58}$

The Annexure detailed the institutional expression of these alternative justice processes, establishing a truth commission and a special high court division. The commission should probe, analyse and publicise the history and nature of the conflict, encourage truth telling and investigate disappearances, while the special high court division should conduct the alternative formal proceedings. The special division was to have its own substantive laws and rules of procedure and should recognise 'traditional and community justice processes in its proceedings' ${ }^{59}$ The special division served the purpose of insulating Uganda's national criminal justice system 
from the peace and reconciliation focused practices of the negotiated justice policy, defined as relevant only in relation to crimes conducted in the LRA conflict.

To the government, the Acholi ritual of mato oput became shorthand for the alternative and traditional accountability mechanism. ${ }^{60}$ Two days after the signing of the Annexure, president Museveni explained: 'what we have said in the agreement is that instead of using this formal Western type of justice we are going to use the traditional justice, a traditional blood settlement mechanism'. ${ }^{61}$ The Agreement committed the government to examine the relevant traditional practices in Acholi, Lango, Teso, Madi and Ankole communities, the latter being the community to which the president and many army commanders belonged.

\section{Alternative sentencing}

Linked to restorative accountability was a regime of 'alternative penalties and sanctions which shall apply, and replace existing penalties' even with respect to serious crimes. ${ }^{62}$ To that end, negotiators 'agreed that a law would be passed to introduce alternative sentences', ${ }^{63}$ but this never happened. They were 'alternative' because they should reflect a range of considerations: the gravity of the crimes, the promotion of individual and collective reconciliation, the rehabilitation of offenders, an individual's admissions or other cooperation with the proceedings (such as confessions, disclosures, or information provision) and the requirement that perpetrators make reparations to victims. The sentencing focus was on reconciliation rather than punishment: Provided one cooperated and showed remorse, penalties could be substantially reduced. ${ }^{64}$

The envisaged alternative sentencing process had three aims: First, to increase the possibility of a buy-in to the accountability process by the LRA high command, thus increasing the likelihood of an end to the conflict. Second, to maintain the formal and judicial nature of the justice process, as LRA crimes would be prosecuted and perpetrators would be sentenced. This formality was important for a future challenge to the admissibility of the cases before the ICC. Lastly, to rehabilitate the rebels. 
The sentencing would be linked to a programme of rehabilitation. Offenders would undergo a programme of psycho-social counselling to restore them as human beings, and social workers, family counsellors and medical staff would be attached to the special division of the high court. ${ }^{65}$ The rehabilitative aspects derived from the nature of the conflict, particularly the fact that many rebels had been abducted initially, forced to commit terrible violence on their own families and communities and internalised the social relations of the LRA. These rehabilitative aspects did not make it into the Agreement and Annexure as it was seen as too deviant from the established view; it was agreed that they should be introduced later. ${ }^{66}$

\section{Individual responsibility}

The fourth feature entailed that individuals, not collectivities, should take responsibility for their conduct. Traditional rituals should occur 'after full accountability' and have 'necessary modifications. ${ }^{97}$ After accepting responsibility, individual perpetrators could be symbolically and materially reconciled with relevant groups, such as victims and ethnic groups. Certain groups were considered to have particular needs: Children were protected from criminal justice proceedings but could, where appropriate, participate in reconciliation processes, while the experiences, views and concerns of women and girls should be recognised and built into the implementation of the justice policy. ${ }^{68}$

The first individual to go through this process was supposed to have been Otti. As he was accessible to the peace process and understood the alternative accountability process, there was a verbal agreement for him to come back to Uganda, be subjected to the process, and send back

word to the other LRA/M leaders that he was OK: he had not been killed or sent to The Hague. ${ }^{69}$ Otti was, however, killed by Kony in October 2007, revealing how heavily the accountability mechanism - and the peace process in general - relied on Otti. ${ }^{70}$ Otti represented a faction within the LRA/M that was interested in a negotiated solution, although not at any cost. ${ }^{71}$ 


\section{Forward-looking victimhood}

Lastly, victims were conceptualised in a forward-looking perspective. Their suffering would be 'honour[ed]' and alleviated by 'promoting lasting peace with justice', the chief means being the demobilisation of the LRA. ${ }^{72}$ The dignity of victims would not be restored by the imprisonment of their tormentors, but rather through the latter's admissions of guilt and truth-telling and the receipt of reparations from the state. It was the view of the mediators that '[there will be] no shady deals, but you say "we are not putting this person in prison" because [prisons] have no answers to victims' ${ }^{73}$ Thus, the rehabilitation of perpetrators derived not from political expediency, but aimed to restore northern Uganda. This explains the unusual sentence that the 'Parties agree that it is essential ...to promote and facilitate their [the victims'] right to contribute to society'. ${ }^{74}$

By means of the five elements identified in the present interpretation, the Agreement and Annexure carved out a zone of possible agreement between the LRA/M leaders and the requirements of the Rome Statute. It was, however, a zone that bewildered observers, who found the agreement 'not entirely clear' 75 and 'rais[ing] more questions than it answers about the handling of LRA crimes'. ${ }^{76}$ Worse, it confused the LRA/M leadership. In his limited communication with the chief mediator, Riek Machar, UN Envoy Chissano, and Acholi elders, Kony repeatedly asked for clarification of the justice policy. ${ }^{77}$ Dominic Ongwen, another wanted member of the LRA/M leadership, told Acholi elders that senior LRA/M commanders would prevent Kony from signing the Final Peace Agreement unless their future prospects and demobilization packages were clearly defined. ${ }^{78}$ The following part of the article argues that the negotiators and mediators' pursuit of international legitimation explains both the substance and form of the accountability and reconciliation regime. 


\section{In pursuit of legitimation}

This section analyses the practices of legitimation that connected participants to the Juba Peace Process with the ICC and its compliance constituency. It advances two interlinked arguments. First, mediators and negotiators' pursuit of legitimation of the peace agreement by the ICC and its compliance constituency structured the agreement in fundamental ways by subjecting its substance and form to the perceived need for its international legitimation. Secondly, this pursuit led negotiators and mediators to formulate a justice policy that in their eyes was compatible with the Rome Statute.

\section{Juba participants' pursuit of international legitimation}

Given the social structure in the field of international justice and the indictment of the LRA/M leaders, the central incompatibility in the Juba negotiations was between the LRA/M and the ICC, two opposing 'audiences' for peace agreement legitimation. On the question of accountability, the government and the LRA/M occupied a zone of possible agreement, having developed a shared understanding of the need for a solution that did not involve prosecution of the LRA/M leaders. In contrast, the ICC and its compliance community understood accountability very differently from the LRA/M and the government, emphasising the duty to prosecute international crimes.

The incompatibility between the ICC and the LRA/M structured the negotiations, engaging negotiators and mediators in the workshop that explored international criminal law vis-àvis traditional and national legal orders. As a result, the parties agreed on some form of national proceedings. However, the incompatibility affected the justice policy in a more fundamental and constitutive sense, as participants constructed the justice policy and formulated the Agreement and Annexure with a view to their international legitimation. States a member of the mediation team, 
The way to read the agreements and the text as it evolved is that you were drafting [it] to answer some of the critics of the [peace] process. Immobilize them, so they couldn't criticize it.

Furthermore,

Accountability through an agreement was always going to be difficult and therefore we couldn't come away from Juba with an agreement that would be shot to pieces by everyone, with an international outcry about the [policy] package. ${ }^{79}$

In an official statement, Ruhakana Rugunda, the minister for internal affairs and chief government negotiator, was more diplomatic, explaining that 'the objective [of the negotiations on accountability and reconciliation] is to come up with a solution that will not only be acceptable to the victims, but also acceptable to the affected, the country and the international community' ${ }^{80} \mathrm{~A}$ member of the LRA/M delegation describes the search for an internationally acceptable solution:

When we came to that [agenda item], people came and really took the ideas of what happened in Sierra Leone, what happened in Columbia. There was this [advisor] ..., who came with a huge document... [Interviewer: What did it suggest?] Very utopian things about how to handle the matter, the problems of Kony. ${ }^{81}$

Rather than agreeing on a solution and subsequently seek to legitimise it, Juba participants worked to agree on an internationally legitimisable solution. It therefore had to comply with the Rome Statute. ${ }^{82}$ According to an observer participant, "what the architects in Juba did was to study the Rome Statute very carefully and work within the framework [of it]. And of course, working on the principle of complementarity is still working within the principle of the Rome Statute'. ${ }^{83}$ Furthermore,

Probably [building a robust complementarity system] is one way that you can convince the international community that you are actually serious about the question of ending impunity. ... so they [the conflict parties] had to acknowledge 'yes the best would be [to have] national trials.' And that's how the question of the War Crimes Division came up. ${ }^{84}$ 
A Swiss advisor to the mediation team concurs:

Following long nights of discussions I was comfortable that a solution could be found through the creation of some form of special court that would operate within Uganda. This concept was vague in the beginning. But we did have a clear idea of alternatives [to ICC trials] that could deliver some form of justice without prejudicing the ICC. ${ }^{85}$

While another member of the mediation team argued that Uganda regained jurisdiction over the LRA/M case by getting the rebels to the negotiation table, the government chief negotiator repeatedly stressed that the Agreement did not contest the ICC's authority. For instance, Rugunda argued that,

[The ICC's] mandate is not under challenge. On the contrary, [the] government of Uganda, and Uganda as a country is a state party to ICC. So people may raise issues about ICC, nevertheless, Uganda fully supports the role and mandate of the International Criminal Court. ${ }^{86}$

The legitimisable justice policy, however, relied on a notion of complementarity that differed from that of the ICC. Coterminous with the negotiations, ICC Chambers were beginning to interpret the meaning of complementarity in concrete cases, adopting a 'strict' understanding of admissibility: a case was inadmissible if domestic courts prosecuted the same person for the same conduct. ${ }^{87}$ While this interpretation emerged for the first time in February 2006, negotiators and mediators operated with a much broader notion of complementarity. ${ }^{88}$

Nouwen writes that Uganda's referral letter, submitted in December 2003, 'followed the shorthand description of complementarity, dominant in the academic literature at the time, as a test of the willingness and ability of the overall justice system of a state with jurisdiction over the alleged acts'. ${ }^{89}$ Juba participants worked with this 'shorthand' interpretation of complementarity rather than the one developing through the ICC's case law. Thus, respective members of the mediation and government teams focused on political will and judicial competences and credibility: 
We now needed to demonstrate in the draft [i.e. Agreement] that ... there would be no point for the ICC to go ahead with the prosecution, because Uganda has the competence to do it. The judges are good, some of the judges are in the ICC. ${ }^{90}$

Given the legitimacy requirements in internationally judicialised peace processes, the imperative of international legitimacy took priority over the need for an agreement that could convince the LRA/M leaders. To some extent, the two objectives were linked. According to a member of the mediation team, '[it] wouldn't help anybody to offer a full blown amnesty because it might not be [internationally] respected, but only end up putting the government under pressure'. ${ }^{91}$ Furthermore, according to participants, it was 'very important' to have international legitimacy, since Kony would not trust a solution that did not deal with the arrest warrants. ${ }^{92}$ In fact, Kony had mentioned the fate of Charles Taylor several times, fearing according to his peace delegation that the government 'will hand him over to the ICC like Nigeria handed over Charles Taylor to the Special Court for Sierra Leone'. ${ }^{93}$ The legitimacy requirements were also indicated in participants' strategies for legitimation.

\section{Legitimation strategies}

Juba participants used four legitimation strategies aimed at the diverse audiences in the conflict network: national legitimation, linguistic deception, sequencing of controversial aspects and coalition building. First, a process of grassroots consultation by the government would legitimise the justice policy nationally. As the Agreement was controversial, it needed popular consent. However, ordinary people were not the primary audience of the national consultation: it was hoped that legitimation from below could diffuse upwards, making international condemnation more difficult. ${ }^{94}$ The government therefore embarked on an extensive national consultation process in October 2007, visiting all regions of the country; the LRA/M delegation carried out a more limited consultation in the north. The pursuit of national and international legitimation was clear from comments by Rugunda: 'The ICC has its own mandate but also the people of the eastern and 
northern Uganda are airing out their constitutional right. We will be able to meet the essential requirements of the victims and the international legal requirements'. ${ }^{95}$

Second, the Accords were written in a language that implied a relatively conventional justice process, while still 'enshrining' an alternative justice system. According to a participant, 'on the face of it, it looks like a prosecution-based agreement. But actually it rewrites the rules of the court'. ${ }^{96}$ By using terms such as 'accountability', 'investigation', 'prosecution', 'proceedings', and 'sentences and sanctions', the agreements implied a conventional justice process and met the norms of international justice. Terms such as 'alternative', 'appropriate' and 'modified' were signifiers for the agreed non-conventional justice process. The linguistic deception was an effort to reach both ends of the polarised conflict network. An attempt to broker support by means of a 'multivocal legitimation strategy', ${ }^{97}$ the Agreement and Annexure spoke in conventional terms to the international community and in alternative terms to the LRA/M. ${ }^{98}$ The result, however, was an 'unclear' agreement. ${ }^{99}$

Third, the two documents sequenced the presentation of the more controversial aspects of the justice policy, such as the creation of a special court and the details of the alternative sentencing regime; the rehabilitative aspects were left out entirely and conveyed in interviews. According to a member of the mediation team, they wanted to get people 'excited' about the Agreement first and then introduce more details in the Annexure later. ${ }^{100}$ Furthermore, the parties had formulated the Annexure before the national consultation took place, but wanted to give the appearance that the special high court division came out of the consultation process; this explains why the press got wind of the special court already in August 2007, before the national consultation. ${ }^{101}$

A last legitimation strategy entailed consultation with the ICC, the Security Council and donor countries, trying to build a coalition for the justice policy and the political solution. 
Chissano, in his role as broker, met with the LRA/M leadership and the ICC prosecutor, briefed the Security Council and liaised with the international community. ${ }^{102}$

While national communities endorsed the Agreement, the legitimation strategies were unsuccessful at the international level. The ICC and its compliance constituency did not legitimise the justice policy and, moreover, interpreted it as a contestation of the ICC's legitimacy. The PreTrial Chamber, the Office of the Prosecutor (OTP) and the Registry discussed the Agreement in a closed-door status conference in December 2007, agreeing on the continued importance of arresting the LRA/M indictees and expressing disappointment with Chissano's public support for the Agreement. ${ }^{103}$ To the prosecutor, 'providing legal exit strategies to the four individuals sought by the court is undermining the court'. ${ }^{104}$ Members of the ICC's compliance constituency agreed. Richard Goldstone, former prosecutor for the Yugoslavia and Rwanda tribunals, condemned Museveni's support for the Agreement. ${ }^{105}$ Amnesty International and Human Rights Watch did not mention the national consultation process in their extensive research and were not linguistically deceived, instead identifying 'loopholes'. ${ }^{106}$ Amnesty International warned the UN Security Council that a request for deferral of the LRA cases would 'seriously harm the prospect of ending impunity... [and] undermine the effectiveness of the ICC and any deterrent effect it has'. ${ }^{107}$

In response to the perceived threat to the ICC by the Agreement and its Annexure, the Juba peace process was delegitimised by the ICC and its supporters: the process was 'inappropriate', ${ }^{108}$ international support for it 'appease[d] Joseph Kony' ${ }^{109}$ and a Security Council deferral to enable its implementation would amount to rebel 'extortion' and 'blackmail'. 110

\section{Conclusion: Rethinking the role of the ICC in peace processes}

In the words of the ICC prosecutor, 'the OTP is not involved in any way in the negotiations to establish any kind of agreement of national proceedings in Uganda'. ${ }^{11}$ At a factual level, this is correct: the OTP had not decided to become involved and was not physically represented at the 
Talks. At a structural level, however, the OTP and the ICC were in the negotiation room: as demonstrated in this article, the prosecutor's indictment of the LRA leaders, the principle of complementarity, and the ICC's role as dispenser of international legitimacy structured the negotiations and the Agreement on Accountability and Reconciliation. As a result of this constitutive presence of the ICC, negotiators and mediators crafted a justice policy which they perceived as internationally legitimisable. Furthermore, given the social structure and community standards of the field of international justice, international legitimation by the ICC and its compliance constituency required compatibility with the Rome Statute. The Agreement thus recalled 'the requirements' of the Statute and 'in particular the principle of complementarity.' ${ }^{112}$

Schomerus argues that the Juba Talks failed to tackle and transform the narratives and power dynamics that shaped the relationship between the conflict parties, instead adopting a technical and depoliticising approach to conflict resolution. ${ }^{113}$ While it is impossible to know if the LRA/M would have implemented the agreements of a holistic and transformative peace process, it is safe to conclude that efforts to understand and align with the Rome Statute and obtain legitimation from the ICC and its supporters came at the expense of pursuits that may have been more suitable to the objective of achieving a lasting peace.

The argument has implications for our understanding of the role of the ICC in internationally judicialised peace processes: The need for legitimation of peace agreements as well as the legitimacy requirements in the field of international justice draw the ICC into the negotiations in an abstract sense. Efforts are therefore concentrated on understanding the possibilities of the Rome Statute, aligning agreements with its requirements and speaking to its notion of justice. The ICC is thereby structurally constituted as an important third-party actor in the negotiations.

The argument raises two broader questions: will ICC interventions always constitute the ICC as a third-party actor in a subsequent peace process and could this role benefit peace- 
making? Research on two other judicialised peace processes, the Kenyan National Dialogue and Reconciliation process following the 2008 post-election violence and Colombia's Havana Process, provides some tentative answers. These processes suggest that the ICC may become a provider of output legitimacy at a low level of involvement, when it is conducting a preliminary examination of a conflict situation. In Kenya, the ICC prosecutor endorsed the negotiated outputs as well as one of the main implementation products, the report of the Commission of Inquiry into the Post-election Violence. ${ }^{114}$ In Colombia, the prosecutor specifically approved the negotiated justice policy, the Special Jurisdiction for Peace. ${ }^{115}$ In both cases, therefore, the OTP played a peace-supporting role. Furthermore, key participants in these negotiations, such as Kenya's chief mediator and Colombia's president, consulted the ICC prosecutor during the period of negotiation and thus treated the Court as a third-party actor. ${ }^{116}$

Recent developments in Colombia highlight that the ICC is one of several audiences for the legitimation of peace process outputs and, furthermore, that domestic audiences may be a greater source of (de)legitimation than are international bodies. In October 2016, a narrow majority of Colombian voters rejected the peace accords between the government and FARC, de-legitimising the agreement and its controversial justice policy. ${ }^{117}$ Two months later, however, the peace agreements were passed into law by the Colombian parliament. ${ }^{118}$ The Kenyan accords were also legislatively enacted.

The level of involvement, however, is likely to affect the ICC's scope for legitimising peace agreements. ${ }^{119}$ Once the ICC intervention reaches the indictment stage, as it did in Uganda prior to the Juba Talks, it may be difficult for the Court to legitimise an agreement that does not unequivocally commit the parties to prosecute indicted actors or extradite them to The Hague. This is due to the legitimacy requirements pertaining to the field of international justice: as argued above, 'ending impunity' is an overriding concern, while complementarity is understood narrowly. A 
modification of these requirements by the Court's compliance constituency would likely affect the scope of the ICC's third-party role in peace processes. Critical reflection on their shared legitimacy requirements may be a useful starting point for those compliance supporters concerned with harnessing a more peace-supportive role for the ICC.

This article has analysed the Juba peace negotiations on accountability and reconciliation, advancing a new interpretation of the Agreement on Accountability and Reconciliation and explaining its ambiguous nature in terms of negotiators and mediators' pursuit of international legitimation. This argument contributes to scholarship on the Juba Peace Talks and transitional justice in Uganda. A more general contribution stems from the argument's implications for our understanding of the informal third-party role of the ICC in internationally judicialised peace processes. As the ICC becomes a provider or withholder of legitimacy, negotiators and mediators direct their thinking, words and deeds upwards, away from conflict dynamics, and towards the Court and its supporters. ICC prosecutors have consistently claimed that their arrest warrants bring rebels to the negotiation table. ${ }^{120}$ While this may or may not be true, this article has demonstrated that ICC warrants have the effect of bringing also the Court into the negotiation room.

\section{Acknowledgements}

I am grateful to Ben Schiff and Louise Chappell for encouraging me to explore issues of legitimacy in situations of ICC involvement. I would also like to thank the reviewers of $J E A S$ for their helpful comments on the article. All errors remain my own.

\section{Notes}

\footnotetext{
${ }^{1}$ Allen, Trial Justice; Kakaire, "Ugandan Mediator Critical"; Lomo and Otto, "Not a Crime to Talk."

${ }^{2}$ Orentlicher, "'Settling Accounts' Revisited"'; Unger and Wierda, "Pursuing Justice in Ongoing Conflict."

3 "Letter to Security Council," para. 7; Moreno-Ocampo, Building a Future on Peace and Justice, 9.

${ }^{4}$ Buchanan and Keohane, "The Legitimacy of Global Governance Institutions"; Clark, "Legitimacy in a Global Order"; Schmidt, "Democracy and Legitimacy in the European Union Revisited."

${ }^{5}$ Horton, "Political Legitimacy, Justice and Consent"; Powell, "Two Courts Two Roads."
} 
${ }^{6}$ Waal, "Violence and Peacemaking," 17.

${ }^{7}$ Salamanca, "Colombia" 27.

${ }^{8}$ Jung and Shapiro, "South Africa's Negotiated Transition"; Rynhold and Cohen, "Envisaging a Peace Referendum."

${ }^{9}$ Arnault, "Legitimacy and Peace Processes"; Goddard, "Brokering Peace."

${ }^{10}$ Mason, "Mediation in African Peace Processes," 15.

${ }^{11}$ Bell, "Peace Agreements"; Sheeran, "International Law, Peace Agreements."

${ }^{12}$ Bell, "Peace Agreements," 377-378.

${ }^{13}$ Kastner, "Towards Internalized Legal Obligations."

${ }^{14}$ Mackay, "Multimodal Legitimation," 325.

${ }^{15}$ Bexell, "Global Governance, Legitimacy and (De)Legitimation."

${ }^{16}$ Lund and Sikor, "Access and Property"; Shankar, "The Embedded Negotiators."

${ }^{17}$ Goddard, "Brokering Peace," 505.

${ }^{18}$ Laura Filardo, "A Comparative Study of the Discursive Legitimation"; Jung and Shapiro, "South Africa's Negotiated Transition."

${ }^{19}$ Clark, "Legitimacy in a Global Order"; Goddard, "Brokering Peace"; Zaum, "International Organizations, Legitimacy, and Legitimation."

${ }^{20}$ Ibid.; see also Bexell, "Global Governance, Legitimacy and (De)Legitimation."

${ }^{21}$ Goddard, "Brokering Peace."

${ }^{22}$ Ibid.

${ }^{23}$ Kerr, "International Judicial Intervention."

${ }^{24}$ Gissel, "Justice Tides."

${ }^{25}$ Bernstein, "Legitimacy in Intergovernmental and Non-State Global Governance."

${ }^{26}$ Ibid., 19.

${ }^{27}$ Arsanjani and Reisman, "The Law-in-Action."

${ }^{28}$ Alter, The New Terrain of International Law, 53.

${ }^{29}$ Allen, Trial Justice; Arnould, "Transitional Justice and Democracy in Uganda"; Branch, "Uganda's Civil War"; Finnström, "Reconciliation Grown Bitter"; Freeland, "Rebranding the State"; Nouwen, Complementarity in the Line of Fire; Roach, "Multilayered Justice"; Rodman and Booth, "Manipulated Commitments"; Schomerus, "Even Eating".

${ }^{30}$ Apuuli, "The ICC's Possible Deferral"; Greenawalt, "Complementarity in Crisis"; see also Rodman and Booth, "Manipulated Commitments."

${ }^{31}$ Branch, Displacing Human Rights; Dolan, Social Torture; Finnström, Living with Bad Surroundings.

${ }^{32}$ Schomerus, "Even Eating," 138. 
${ }^{33}$ Dolan, Social Torture; Schomerus, "Even Eating."

${ }^{34}$ Schomerus, "Even Eating," 68.

35 The Monitor, "I Am Not a Terrorist."

${ }^{36}$ Mukasa, "Museveni Gives Joseph Kony Final Peace Offer."

${ }^{37}$ US Embassy, "A/S Frazer Discusses."

${ }^{38}$ Government of Uganda, Referral of the Situation.

39 "The Juba Peace Initiative."

${ }^{40}$ LRA/M, Opening Speech.

${ }^{41}$ Atkinson, "'The Realists in Juba'?"

${ }^{42}$ Otim and Wierda, "Justice at Juba," 23.

${ }^{43}$ Afako, "Reconciliation and Justice."

${ }^{44}$ Interview, member of the LRA/M delegation, Kampala, 23 March 2011.

${ }^{45}$ Otim and Wierda, "Justice at Juba," 23.

${ }^{46}$ LRA/M, A Synopsis on Uganda Peace Talks.

${ }^{47}$ US Embassy, "Northern Uganda Notes (June 4-16, 2007)."

${ }^{48}$ Quoted in ibid.

${ }^{49}$ Government of Uganda and LRA/M, Agreement on Accountability and Reconciliation.

${ }^{50}$ see also Apuuli, "Taking Stock of the First Arrest Warrants"; Nouwen, Complementarity in the Line of Fire, ch. 3.

${ }^{51}$ Government of Uganda and LRA/M, Agreement on Accountability and Reconciliation, cl. 2.1.

${ }^{52}$ Ibid., cl. 14.5 and 14.6 .

${ }^{53}$ Interviews, member of the LRA/M delegation, Kampala, 23 March 2011 and member of the mediation team, London, UK, 4 February 2013.

${ }^{54}$ Government of Uganda and LRA/M, Agreement on Implementation, para. 37.

${ }^{55}$ Government of Uganda and LRA/M, Agreement on Accountability and Reconciliation, cl. 3.1 and 3.2.

${ }^{56}$ Ibid., cl. 4.

57 "The Juba Peace Initiative," 7.

${ }^{58}$ Government of Uganda and LRA/M, Agreement on Accountability and Reconciliation, cl. 5.2 and 5.3.

59 "The Juba Peace Initiative," 8.

${ }^{60}$ Interviews, members of the government delegation to the Juba Talks, Kampala, 5 April 2011 and 22 May 2011 , respectively. 
${ }^{61}$ Quoted in Greenawalt, "Complementarity in Crisis," $115 \mathrm{n}$.

${ }^{62}$ Government of Uganda and LRA/M, Agreement on Accountability and Reconciliation, cl. 6.3, cl. 6.3

63 "The Juba Peace Initiative," 7.

${ }^{64}$ Interview, member of the mediation team, London, UK, 4 February 2013.

${ }^{65}$ Ibid.

${ }^{66}$ Ibid.

${ }^{67}$ Government of Uganda and LRA/M, Agreement on Accountability and Reconciliation, cl. 6.3, Part 1 and cl. 3.1

${ }^{68}$ Ibid., cl. $12 . i v$ and 11 ii.

${ }^{69}$ Interview, member of the mediation team, London, 4 February 2013.

${ }^{70}$ See also Baaré, "Negotiating Security Issues," 27.

${ }^{71}$ Schomerus, "Even Eating," 177-181.

${ }^{72}$ Government of Uganda and LRA/M, Agreement on Accountability and Reconciliation, preamb. para. 1.

${ }^{73}$ Interview, member of the mediation team, London, 4 February 2013.

${ }^{74}$ Government of Uganda and LRA/M, Agreement on Accountability and Reconciliation, cl. 8.1.

${ }^{75}$ Wegner, Ambiguous Impacts, 20.

${ }^{76}$ Greenawalt, "Complementarity in Crisis," 118.

${ }^{77}$ Machar, "Report and Recommendations, " para. 14; Schomerus, "Even Eating, " 233, $238,242$.

${ }^{78}$ Schomerus, "Even Eating,” 245; US Embassy, "Kony Living."

${ }^{79}$ Interview, member of the mediation team, London, UK, 4 February 2013.

${ }^{80}$ Rugunda, Update on the Juba Peace Process.

${ }^{81}$ Interview, member of the LRA/M delegation, Kampala, 23 March 2011. The identity of the advisor is known to the author and the person was interviewed but requested anonymity.

${ }^{82}$ See also Nouwen, Complementarity in the Line of Fire, ch. 3

${ }^{83}$ Interview, observer participant, 12 June 2010.

${ }^{84} \mathrm{Ibid}$. The War Crimes Division of the High Court was later named the International Crimes Division of the High Court.

${ }^{85}$ Hottinger, "Interview: Julian Hottinger," 15.

${ }^{86}$ Quoted in Clottey, "Uganda's Govt Denies Media Reports."

${ }^{87}$ Nouwen, Complementarity in the Line of Fire, 53; see also Jurdi, "Some Lessons on Complementarity."

${ }^{88}$ International Criminal Court, Decision on the Prosecutor's Application for Warrants of Arrest. 
${ }^{89}$ Nouwen, Complementarity in the Line of Fire, 120-121.

${ }^{90}$ Interview with member of the mediation, Kampala, 19 April 2011. See also Kazooba and agencies, "LRA Threatens War." The same view was expressed by the Chairman of the Amnesty Commission, Justice Onega, in Maseruka and Ariko, "Scrap Blanket Amnesty."

${ }^{91}$ Interview, member of the mediation team, London, UK, 4 February 2013.

92 Interviews, member of the mediation team, Kampala, 19 April 2011, and observer participant, Kampala, 12 June 2010.

${ }^{93}$ US Embassy, "Northern Uganda Notes (July 15-28, 2007)"; see also Unger and Wierda, "Pursuing Justice," 271.

${ }^{94}$ Interview, member of the mediation team, London, UK, 4 February 2013.

${ }^{95}$ Kazooba and agencies, "LRA Threatens War."

${ }^{96}$ Interview, member of the mediation team, London, UK, 4 February 2013.

${ }^{97}$ Goddard, "Brokering Peace."

${ }^{98}$ Rodman and Booth, "Manipulated Commitments," 294.

${ }^{99}$ Greenawalt, "Complementarity in Crisis," 120.

${ }^{100}$ Interview, member of the mediation team, London, UK, 4 February 2013.

${ }^{101}$ Nyakairu, "Govt Plans Special Court."

102 International Criminal Court, "[Transcript, Status Conference]"; US Embassy Kampala, "Northern Uganda: Proposed Press Statement."

${ }^{103}$ International Criminal Court, "[Transcript, Status Conference]."

${ }^{104}$ Ibid., 29.

${ }^{105}$ Quoted in Apuuli, "The ICC's Possible Deferral," 811.

106 "Uganda: Agreement and Annex on Accountability," 22.; "The June 29 Agreement."

107 "Letter to Security Council."

108 "Uganda: Agreement and Annex on Accountability," 4.

${ }^{109}$ International Criminal Court, The Importance of Justice.

${ }^{110}$ Moreno-Ocampo, Building a Future on Peace and Justice, 9.

${ }^{111}$ International Criminal Court, "[Transcript, Status Conference]" 31.

${ }^{112}$ Government of Uganda and LRA/M, Agreement on Accountability and Reconciliation, preambular para. 3

113 Schomerus, "Even Eating."

${ }^{114}$ Office of the Prosecutor, "ICC Prosecutor Supports."

115 Office of the Prosecutor, "Statement of ICC Prosecutor," para. 3. 


\footnotetext{
${ }^{116}$ Interview with member of the mediation team to Kenya National Dialogue and Reconciliation, Nairobi, 5 May 2011; Office of the Prosecutor, "Statement of ICC Prosecutor," para. 4.

${ }^{117}$ BBC, "Colombia Referendum."

${ }^{118}$ BBC, "Colombian Congress."

${ }^{119}$ On a framework for studying levels of ICC involvement, see Gissel, "Justice Tides."

${ }^{120}$ Bensouda, "International Justice and Diplomacy."
}

\section{Bibliography}

Afako, Barney. "Reconciliation and Justice: 'Mato Oput' and the Amnesty Act." In Protracted Conflict, Elusive Peace: Initiatives to End the Violence in Northern Uganda. Accord issue 11, edited by Lucima Okello, 64-67. London: Conciliation Resources, 2002.

Allen, Tim. Trial Justice : The International Criminal Court and the Lord's Resistance Army. African Arguments. London: Zed, 2006.

Alter, Karen J. The New Terrain of International Law: Courts, Politics, Rights. Princeton: Princeton University Press, 2014.

Apuuli, Kasaija Phillip. "The ICC's Possible Deferral of the LRA Case to Uganda." Journal of International Criminal Justice 6, (2008): 801-813. doi: 10.1093/jicj/mqn046.

Apuuli, Kasaija Phillip. "Taking Stock of the First Arrest Warrants of the International Criminal Court." African Centre for the Constructive Resolution of Disputes (ACCORD) 7, no. 1 (2007): 43-62. http://www.accord.org.za/ajcr-issues/\%ef\%bf\%bctaking-stock-of-the-first-arrest-warrants-of-theinternational-criminal-court/

Arnault, Jean. "Legitimacy and Peace Processes." In Legitimacy and Peace Processes: From Coercion to Consent, edited by Alexander Ramsbotham and Achim Wennmann, 21-25. London: Conciliation Resources, 2014.

Arsanjani, Mahnoush H. and W. Michael Reisman. "The Law-in-Action of the International Criminal Court." American Journal of International Law 99, no. 2 (2005): 385-403. doi: 10.2307/1562504

Atkinson, Ronald R. "'The Realists in Juba'? an Analysis of the Juba Peace Talks." In The Lord's Resistance Army: Myth and Reality, edited by Tim Allen and Koen Vlassenroot, 205-222. London: Zed Books, 2010.

Baaré, Anton. "Negotiating Security Issues in the Juba Process." In Negotiating Disarmament: Reflections on Guns, Fighters and Armed Violence in Peace Processes, edited by Cate Buchanan, 20-32. Geneva: Centre for Humanitarian Dialogue, 2008.

BBC. "Colombia Referendum: Voters Reject FARC Peace Deal." 3 October 2016. http://www.bbc.com/news/world-latin-america-37537252. Accessed 4 October 2016. 
BBC. "Colombian Congress Ratifies New FARC Peace Accord." 1 December 2016. http://www.bbc.com/news/world-latin-america-38165752. Accessed 4 January 2017.

Bell, Christine. "Peace Agreements: Their Nature and Legal Status." The American Journal of International Law 100, no. 2 (2006): 373-412. http://www.jstor.org/stable/3651152.

Bernstein, Steven. "Legitimacy in Intergovernmental and Non-State Global Governance." Review of International Political Economy 18, no. 1 (2011): 17-51. doi: 10.1080/09692290903173087.

Bexell, Magdalena. "Global Governance, Legitimacy and (De)Legitimation" Globalizations 11, no. 3 (2014): 289-299. doi: 10.1080/14747731.2014.919744.

Branch, Adam. Displacing Human Rights: War and Intervention in Northern Uganda. New York: Oxford University Press, 2011.

Branch, Adam. "Uganda's Civil War and the Politics of ICC Intervention." Ethics \& International Affairs 21, no. 2 (2007): 179. doi: 10.1111/j.1747-7093.2007.00069.x

Buchanan, Allen and Robert O. Keohane. "The Legitimacy of Global Governance Institutions." In Legitimacy, Justice and Public International Law, edited by Lukas H. Meyer, 29-57. Cambridge: Cambridge University Press, 2009.

Clark, Ian. "Legitimacy in a Global Order" Review of International Studies 29, (2003): 75-95. doi: $10.1017 / \mathrm{S} 0260210503005904$.

Clottey, Peter. "Uganda's Govt Denies Media Reports on War Crimes Court." Voice of America, 20 August, 2007.

de Waal, Alex. "Violence and Peacemaking in the Political Marketplace." In Legitimacy and Peace Processes: From Coercion to Consent, Accord Issue 25, edited by Alexander Ramsbotham and Achim Wennmann, 17-20. London: Conciliation Resources, 2014.

Dolan, Chris. Social Torture: The Case of Northern Uganda, 1986-2006. Human Rights in Context. New York: Berghahn Books, 2009.

Filardo, Laura. "A Comparative Study of the Discursive Legitimation of the Agreement by the Four Main Northern Irish Political Parties Throughout Time." Ethnopolitics 7, no. 1 (2008): 21-42. doi: $10.1080 / 17449050701846634$

Finnström, Sverker. Living with Bad Surroundings. Durham: Duke University Press, 2008.

Finnström, Sverker. "Reconciliation Grown Bitter? War, Retribution, and Ritual Action in Northern Uganda." In Localizing Transitional Justice: Interventions and Priorities After Mass Violence, edited by Rosalind Shaw, Lars Waldorf, and with Pierra Hazan, 135-156. Stanford: Stanford University Press, 2010 .

Freeland, Valerie. "Rebranding the State: Uganda's Strategic use of the International Criminal Court." Development and Change 46, no. 2 (2015): 293-319. doi: 10.1111/dech.12147. 
Gissel, Line Engbo "Justice Tides: How and When Levels of ICC Involvement Affect Peace Processes." International Journal of Transitional Justice 9, no. 3 (2015): 428-448. doi: 10.1093/ijtj/ijv021.

Goddard, Stacie E. "Brokering Peace: Networks, Legitimacy, and the Northern Ireland Peace Process." International Studies Quarterly 56, (2012): 501-515. doi: 10.1111/j.1468-2478.2012.00737.x.

Government of Uganda. Referral of the Situation Concerning the Lord's Resistance Army. Kampala: Government of Uganda, 2003. Copy on file with the author.

Government of Uganda and LRA/M. Agreement on Accountability and Reconciliation. Vol. 29 June 2007.

Government of Uganda and LRA/M. Agreement on Implementation and Monitoring Mechanisms. Vol. 29 February 2008.

Greenawalt, Alexander K. A. "Complementarity in Crisis: Uganda, Alternative Justice, and the International Criminal Court." Virginia Journal of International Law 50, no. 1 (2009): 107. http://www.vjil.org/assets/pdfs/vol50/issue1/Greenawalt-Final-10-27.pdf

Horton, John. "Political Legitimacy, Justice and Consent" Critical Review of International Social and Political Philosophy 15, no. 2 (2012): 129-148. doi: 10.1080/13698230.2012.651015.

Hottinger, Julian. "Interview: Julian Hottinger. Perspectives of a Mediator." In Initiatives to End the Violence in Northern Uganda: 2002-2009 and the Juba Peace Process. Update to Accord Issue 11, edited by Elizabeth Drew, 15-15. London: Conciliation Resources, 2010.

International Criminal Court. Decision on the Prosecutor's Application for Warrants of Arrest, Article 58, 10 Feb 2006, Situation in the DRC. Doc. ICC-01/04-520-Anx2. The Hague: International Criminal Court, 2006.

International Criminal Court. The Importance of Justice in Securing Peace. Doc. RC/ST/PJ/INF.3. The Hague: International Criminal Court, 2010.

International Criminal Court. [Transcript, Status Conference, 11 December 2007] Doc. ICC-02/04-01/15-T3-ENG ET WT 11-12-2007 1/57 SZ PT. The Hague: International Criminal Court, 2007.

"The Juba Peace Initiative (JPI) July 2006 - March 2008: Analysis of the Validity and Applicability of the Juba Agreements in the Absence of a Signature on the Final Agreement." Kampala: Civil Society Organisations for Peace in Northern Uganda, 2009.

Jung, Courtney and Ian Shapiro. "South Africa's Negotiated Transition: Democracy, Opposition, and the New Constitutional Order." Politics \& Society 23, no. 3 (1995): 269-308. doi: $10.1177 / 0032329295023003002$.

Jurdi, Nidal Nabil. "Some Lessons on Complementarity for the International Criminal Review Conference." South African Year Book of International Law (April, 2010): 28-56. http://hdl.handle.net/10520/EJC100132.

Kakaire, Apollo. "Ugandan Mediator Critical of ICC Indictments." Institute for War and Peace Reporting, 15 April, 2006. 
Kastner, Philipp. "Towards Internalized Legal Obligations to Address Justice and Accountability? A Novel Perspective on the Legal Framework of Peace Negotiations." Criminal Law Forum 23, no. 1 (2012): 193. doi:10.1007/s10609-012-9174-4.

Kazooba, Charles and agencies. "LRA Threatens War Over Museveni, Kabila Pact." The New Times, 13 September, 2007.

Kerr, Rachel. "International Judicial Intervention: The International Criminal Tribunal for the Former Yugoslavia." International Relations 15, no. 2 (2000): 17-26. doi:10.1177/004711780001500202.

"Letter to Security Council." Amnesty International, 1 April 2008.

Lomo, Zachary and James Otto. Not a Crime to Talk: Give Peace a Chance in Northern Uganda, Press Release, 24 July 2006. Kampala: Refugee Law Project and Human Rights Focus, 2006.

LRA/M. Opening Speech, 2006.

LRA/M. A Synopsis on Uganda Peace Talks, 2007.

Lund, Christian and Thomas Sikor. "Access and Property." Development and Change 40, no. 1 (2009): 1. doi:10.1111/j.1467-7660.2009.01503.x.

Mackay, Rowan R. "Multimodal Legitimation: Selling Scottish Independence." Discourse \& Society 26, no. 3 (2015): 323-348. doi: 10.1177/0957926514564737.

Maseruka, Josephine and Charles Ariko. "Scrap Blanket Amnesty, Says Onega." The New Vision, 14 August, 2007.

Mason, Simon J.A. "Mediation in African Peace Processes: Carefully Comparing Apples and Oranges." In Unpacking the Mystery of Mediation in African Peace Processes, edited by Annika Åberg, Sabina Laederach, David Lanz, Jonahan Litscher, Simon J. A. Mason and Damiano Sguaitamatti, 7-20. Zurich and Bern: Center for Security Studies and Swisspeace, 2008.

Moreno-Ocampo, Luis. Building a Future on Peace and Justice, Speech, Nuremberg, 24/25 June 20072007.

Mukasa, Henry. "Museveni Gives Joseph Kony Final Peace Offer." The New Vision, 16 May 2006.

Nouwen, Sarah M. H. Complementarity in the Line of Fire: The Catalysing Effect of the International Criminal Court in Sudan. Cambridge: Cambridge University Press, 2013.

Nyakairu, Frank. "Govt Plans Special Court for LRA Leader." The Monitor, 20 August 2007.

Office of the Prosecutor. "ICC Prosecutor Supports Three-Pronged Approach to Justice in Kenya". Press Release, 30 September 2009. The Hague: International Criminal Court.

Office of the Prosecutor. "Statement of ICC Prosecutor, Fatou Bensouda, on the Conclusion of the Peace Negotiations between the Government of Colombia and the Revolutionary Armed Forces of Colombia People's Army." 1 September 2016. The Hague: International Criminal Court. 
Orentlicher, Diane F. "'Settling Accounts' Revisited: Reconciling Global Norms with Local Agency." The International Journal of Transitional Justice 1, no. 1 (2007): 10-22. doi: 10.1093/ijtj/ijm010.

Otim, Michael and Marieke Wierda. "Justice at Juba: International Obligations and Local Demands in Northern Uganda." In Courting Conflict? Justice, Peace and the ICC in Africa, edited by Nicholas Waddell and Phil Clark, 21-28. London: Royal African Society, 2008.

Powell, Emilia Justyna. "Two Courts Two Roads: Domestic Rule of Law and Legitimacy of International Courts." Foreign Policy Analysis 9, (2013): 349-368.

Roach, Steven C. "Multilayered Justice in Northern Uganda: ICC Intervention and Local Procedures of Accountability." International Criminal Law Review 13, no. 1 (2013): 249-268. doi: 10.1163/1571812301301008.

Rodman, K.A. and P. Booth. "Manipulated Commitments: The International Criminal Court in Uganda." Human Rights Quarterly 35, no. 2 (2013): 271-303. doi: 10.1353/hrq.2013.0027.

Rugunda, Ruhakana. Update on the Juba Peace Process and the Challenges Ahead. Address Delivered by the Hon. Minister of Internal Affairs, Hon. Ruhakana Rugunda at the Launch of the Transitional Justice Project of the Faculty of Law, Makerere University. Kampala: Beyond Juba Project, 2007.

Rynhold, Jonathan and Asher Cohen. "Envisaging a Peace Referendum in Israel: The Legitimisation of Peace Or a Legitimation Crisis? Lessons from Northern Ireland." Civil Wars 6, no. 1 (2003): 85-104. doi: 10.1080/13698240308402527.

Salamanca, Rosa Emilia. "Colombia: Legitimacy, Women and the Havana Peace Talks." In Legitimacy and Peace Processes: From Coercion to Consent, edited by Alexander Ramsbotham and Achim Wennmann. Vol. 25, 26-27. London: Conciliation Resources, 2014.

Schmidt, Vivien A. "Democracy and Legitimacy in the European Union Revisited: Input, Output and Throughput." Political Studies 61, (2013): 2-22. doi: 10.1111/j.1467-9248.2012.00962.x.

Schomerus, Marieke. "Even Eating You Can Bite Your Tongue: Dynamics and Challenges of the Juba Peace Talks with the Lord's Resistance Army." PhD diss., London School of Economics and Political Science, 2012.

Shankar, Shylashri. "The Embedded Negotiators: India's Higher Judiciary and Socioeconomic Rights." In The Activist Tribunals of India, South Africa, and Columbia, edited by Daniel Bonilla Maldonado, 95128. Cambridge: Cambridge University Press, 2013.

Sheeran, Scott P. "International Law, Peace Agreements and Self-Determination: The Case of Sudan." International and Comparative Law Quarterly 60, (2011): 423-458. doi: 10.1017/S0020589311000091.

The Monitor. "I Am Not a Terrorist, I Am a Freedom Fighter, Says Kony." The Monitor, 26 May 2006.

Unger, Thomas and Marieke Wierda. "Pursuing Justice in Ongoing Conflict: A Discussion of Current Practice." In Building a Future on Peace and Justice: Studies on Transitional Justice, Peace and Development, edited by Kai Ambos, Judith Large and Marieke Wierda, 263-302. Berlin and Heidelberg: Springer-Verlag, 2009. 
US Embassy Kampala. "A/S Frazer Discusses LRA, Congo, and Somalia with President Museveni." Doc. 07KAMPALA1449 (14 September 2007). Published by Wikileaks.org, 2007.

US Embassy Kampala. "Northern Uganda Notes (June 4-16, 2007)." Doc. 07KAMPALA1011 (15 June 2007). Published by Wikileaks.org, 2007.

US Embassy Kampala. "Northern Uganda Notes (July 15-28, 2007)." Doc. 07KAMPALA1224 (27 July 2007). Wikileaks.org, 2007.

US Embassy Kampala. "Northern Uganda: Kony Living in a Fool's Paradise." Doc. 08KAMPALA1579 (10 December 2008). Wikileaks.org, 2008.

US Embassy Kampala. "Northern Uganda: Proposed Press Statement to Keep Momentum in the Peace Process." Doc. 07KAMPALA1251 (3 August 2007). Wikileaks.org, 2007.

Zaum, Dominik. "International Organizations, Legitimacy, and Legitimation." In Legitimating International Organizations, edited by Zaum, Dominik, 3-25. Oxford: Oxford University Press, 2013. 